\begin{tabular}{|c|c|c|}
\hline (j) & $\begin{array}{c}\text { Türkiye Tarımsal Araştırmalar Dergisi } \\
\text { dergipark.org.tr/tutad }\end{array}$ & $\begin{array}{l}\text { Turk J Agric Res } \\
\text { 2019, 6(3): 349-355 } \\
\text { @ TÜTAD } \\
\text { ISSN: 2148-2306 }\end{array}$ \\
\hline $\begin{array}{l}\text { UNNIVERSiTESI } \\
\text { Bulimin Nyümanda }\end{array}$ & Derleme / Review & $\begin{array}{l}\text { e-ISSN: 2528-858X } \\
\text { doi: 10.19159/tutad.543576 }\end{array}$ \\
\hline
\end{tabular}

\title{
Tarihi Kayıtlar ile Geçmişten Günümüze Salep Orkideleri
}

\author{
Ömer ÇALIŞKAN*, Dursun KURT \\ Ondokuz Mayls Üniversitesi, Bafra Meslek Yüksekokulu, Bitkisel ve Hayvansal Üretim Bölümü, Bafra-Samsun, TÜRKIYYE
}

\begin{tabular}{|c|c|}
\hline Geliş Tarihi/Received: 22.03.2019 & Kabul Tarihi/Accepted: 02.10 .2019 \\
\hline ORCID ID (Yazar sirasina göre / by author order) & \\
\hline (1D) orcid.org/0000-0003-2235-3184 (D) orcid.org/0000-0001-6697-3954 & \\
\hline
\end{tabular}

Öz: Türkiye'nin sahip olduğu coğrafik konum sayesinde oluşan genel bitki çeşitliliği ve doğal zenginliği, salep orkidesi türlerine de yansımıștır. Nitekim Türkiye orta kuşak salep orkideleri bakımından Avrupa ve Ortadoğu'nun en zengin bölgesidir. Türkiye'nin her köşesinde salep türleri ile karşılaşmak mümkündür. Bu zenginliğe bağlı olarak yüzyıllardır Anadolu topraklarında salep yumruları toplanmış ve kullanılmıştır. Hazırlanan bu eserde geçmişten günümüze salebin kullanım amaçları, toplama kayıtları ve yasal düzenlemelere yer verilmiştir.

Anahtar Kelimeler: Biyoçeşitlilik, etnobotanik, geleneksel kullanım, salep

\section{Salep Orchids from Past to Present with Historical Recordings}

\begin{abstract}
Thanks to its geographical location, the plant diversity and natural wealth of Turkey are reflected in the sahlep orchid species. Indeed, Turkey is the richest region in Europe and the Middle East in terms of the middle climate zone sahlep orchids. It is possible to encounter sahlep orchid species in every corner of Turkey. Due to this wealth, sahlep tubers have been collected and used in Anatolia for centuries. In this work, intented uses, collection records, and legal regulations of sahlep orchids from past to present are included.
\end{abstract}

Keywords: Biodiversity, etnobotany, traditional use, sahlep

\section{Giriş}

Orchidaceae (Orkidegiller) familyasına dâhil türlerin yaşam alanlarında ve fiziksel boyutlarında büyük bir varyasyon görülmektedir. Çok farklı ortamlarda yetişen bu familyaya ait türler temel benzerliklerine göre; epifit (ağaçlar üzerine hava kökleriyle tutunanlar), terrestrial (kökleriyle toprağa bağlı olan orta kuşak orkideler), litofit (taşlara tutunanlar), çürükçül ve parazit orkideler olarak beş gruba ayrılmaktadır. Toprakta yaşayan (terrestrial) orkide türleri, genellikle orta kuşak bölgelerde yayılış göstermekte ve toprak altında yumru, kök veya rizom yapıları bulunmaktadır. Yumrulu olan türler, salep orkideleri olarak adlandırılmakta ve kullanılmaktadır (Bulpitt, 2005; Jalal ve ark., 2008; Hossain, 2011; Pant, 2013;
Attri, 2016; Şen, 2017; Turgay ve Çınar, 2017). Bu çalışmada; salebin kullanım amaçları, toplama kayıtları ve yasal düzenlemeler geçmişten günümüze ele alınmıştır.

\section{Tarihi Kullanım Kayıtları}

Yumrulu salep orkidelerinde ilk kayıt M.Ö. 350 yılında, botaniğin babası olarak adlandırılan Yunan filozof Theophrastus'a aittir. Theophrastus, yumrularından dolay1 bitkilere orchis ismini vermiş ve tıbbi değerinden bahsetmiştir (Kreziou ve ark., 2016). Bunun yanında, I. yüzyılda Yunan doktor Dioscoridesin, M.S. 50-70 y1lları arasında hazırladığı 5 ciltlik Materia Medica (Tıbbi Materyaller) adlı eserinde, salebi çiçek, yaprak ve renkleri hakkında bilgiler vererek tanımlamış ve 
özellikle afrodizyak ve zührevi hastalıkların çözümünde kullanmıştır. Antik Romalılar "Satyrion" ve "Priapiscus" adlariyla isimlendirdikleri içecekleri yapmak için salep yumrularından yararlanmışlar, güçlü bir afrodizyak olduğunu düşünmüşlerdir. Hint pazarlarında ise salep, "salib misri" olarak adlandırılmış ve kullanılmıştır (Singh ve ark., 2012, 2016; Bonte ve ark., 2013).

Salep Türkçe bir kelime olup, Yunancada "salepi", Arapçada "sahlab" olarak isimlendirilmektedir. Yumru oluşturan çok sayıda cins ve ona bağlı tüm orkide türlerinin hepsine salep adı verilmiştir. Aynı zamanda üründen hazırlanan sıcak içecekte yine salep olarak isimlendirilmektedir (Ghorbani ve ark., 2014). İngiliz devlet adamı Oliver Cromwell (1599-1658) zamanında Londra'da dağıtıldığı, sokaklarda sıcak içecek halinde satıldığı bilinmektedir. İngiltere'de "saloop" olarak bilinen içecek 17. ve 18. yüzyılda çok popülerlik kazanmıştır. Salep, kahve ve çayın yaygınlaşmasından önce, popülerliği Anadolu'dan Orta Doğu, İngiltere ve Almanya'ya yayılmış bir içecek olarak bilinmektedir. Avrupa'da kadınlarda kısırlık, düşük, verem, mide problemleri, deri tahrişi ve grip gibi çeşitli durumlar için tavsiye edilmiştir. Yine İngiltere'de, 18. ve 19. yüzy1llarda İngiliz ordusu levazımı arasında yer alıp, hem hasta askerlerin diyet gıdası hem de erzak azaldığ zaman besleyici bir yiyecek olarak kullanılmıştır. İngiltere'de, salep tozu Türkiye'deki gibi; kalınlaşıncaya kadar suya ilave edilir, bunun üzerine portakal çeşnisi veya gül suyu ile lezzetlendirilirdi. Doğu Avrupa, Afganistan, Buhara ve Hindistan gibi birçok yerde yetişme alanı bulan salebin ana üreticisi her zaman Türkiye olmuştur (Kasparek ve Grim, 1999; Kreutz, 2002; Whigham ve Willems, 2003; Işın, 2008; Hossain, 2011).

Özbekistan'ın Buhara kentinde 980 yılında doğan, 19 yaşında doktor unvanı alan ve tıbbın prensi olarak nitelendirilen İbn-i Sina, "El-Kânûn Fî't-T1b" (T1p Kanunu) adlı eserinde saleple ilgili geniş bilgiler vermiştir. Avrupa'da 17. yüzyıla kadar tıp eğitiminin baş eser olarak kullandığı kitapta İbn-i Sina, salebi; afrodizyak, iştah açıcı, balgam artırıcı, felç giderici, zihin açıcı olarak önermekte, nefsi kuvvetlendirici ve ferahlatıcı macunların yapımında kullanımını tarif etmektedir. Endülüs'ün önemli bilim adamlarından Malaga'lı botanikçi, eczacı ve hekim Ziyaeddin İbn El Baytar (1197-1249), 4. Murad'ın başhekimlerinden Emir Çelebi, 2. Selim'in başhekimi Tabib Nidai, Salih bin Nasrullah gibi birçok tıp âlimi, eserlerinde İbni Sina'dan esinlenerek benzer kullanım şekillerini tanımlamışlardır.
Yine I. Mehmet zamanında yaşamış olan Mehmed el Şirvani tarafından önerilen "Macun-u Şahi”nin (Padişah Macunu) başlıca maddesi saleptir. Yazarın risalesinde salep için yazdığı; "Evvel fehm (anlayış kabiliyeti) ziyade eder, dahi yüreğe kuvvet verir ve dahi ciğer ağrısına faide eder ve dahi bevasire gayet nafidir ve hem kulunç giderir ve hem iptidai ikrise nafidir ve küllü maraza faide eder mücerrebdir şahlar macunudur" ifadesi salebin o dönemde tıbbi amaçlı kullanım alanlarını özetlemektedir (Gümüş, 2009). Salep, Osmanlı Sarayı'nın “Halvahane”sinde her sene padişahlar için pişen macunların kaydedildiği defterde de bulunmaktadır. Örneğin; misridat macunu, filozoflar macunu, ferahlatıcı maddeler macunu gibi macunların terkiplerinde önemli miktarda salep bulunmaktadır (Ghorbani ve ark., 2014; Tiğlı, 2015). Osmanlı döneminde saray sunum kaplarının incelendiği bir çalışmada; salep, şerbet, boza gibi çeşitli içecekler için özel tatlı kupaları kullanıldığ 1 belirtilmektedir. O döneme ait, saleplik olarak adlandırılan, kulplu ve kapaklı fincan görseli Şekil 1'de görülmektedir (Pala, 2010).

Ünlü seyyah Evliya Çelebi seyahatnamesinde, sadece İstanbul'da 200 kadar seyyar salepçi esnafinın bulunduğunu belirterek bu satıcıların salep hazırlayışını ve satışını kısaca; "kış günleri onu kurutup havanda un gibi edip şekerle palude gibi pişirip, bakır ibriklerin altında ateşler ile süslü ibrikler ile baharatlı, gülsulu "Rahat-1 can, Sihhatül ebdan, Talim-i nefais (can rahatı, beden sihhati, nefis)" deyip bağırarak geçerler." şeklinde özetlemiştir. Evliya Çelebi'nin ifadesine göre salep; 100 yaşında bir adamı dahi güçlü ve çevik yapar, nükseden ağrıları iyileştirir, görme yeteneğini geliştirir ve vücudu kuvvetlendirir. Osmanlı tarihçisi Ahmed Cavid ise salebin üzüm pekmezi, üzüm suyu ya da balla tatlandırılarak sokaklarda satıldığını, üst sınıfın ise kendi içeceklerini şeker ile tatlandırıp afrodizyak olarak kullanıldığını iddia etmiştir (Işın, 2008; Çalışkan, 2018).

Kaptan Byron'un 1764'te Güney Kutbunu keşfe gittiği seyahatinde, sabahları sulu alkol yerine salep ya da sago içmiştir. Salep iskorbit hastalığından 1stırap çekenler için de faydalı görülmüştür. Kaptan Cook 1768'de Pasifik seyahatinde, iskorbit hastalığını önlemek için 40 pound (yaklaşık 18 kilo) salep tozu depolamıştır. Fransız çikolata üreticisi, 1800 yılında salep ile "analeptik çikolata" yapmıştır. Bu ürünü hafif ve besleyici olarak zayıf insanlara, hassas ciğerleri olanlara ve kronik hastalara önermiştir. Diğer taraftan, 1838'de Friedrich Unger, Yunanistan ve Türkiye'de salep satıcılarını şöyle tanımlamaktadır; "Onlar erkence, hava ağarınca 

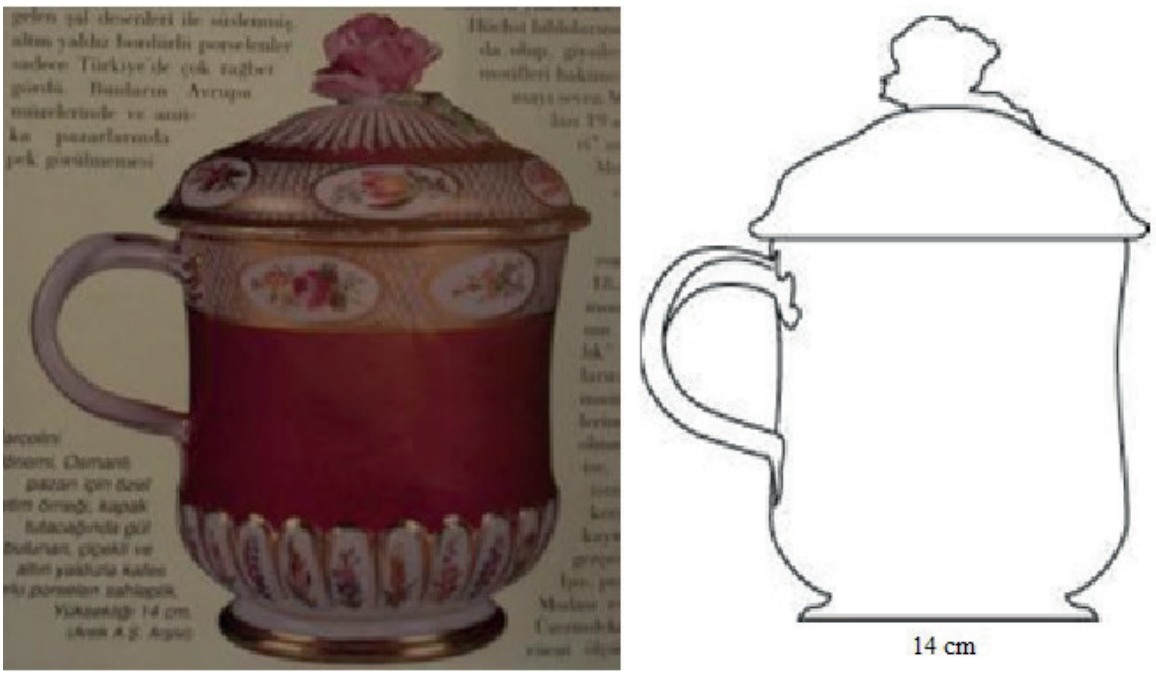

Şekil 1. Saleplik: Osmanlı pazarı için özel üretim örneği, Antik AŞ. Arşivi (Pala, 2010)

görünürler. Çift bölümlü ince maşrapalarının alt kısmı salebin sıcak kalması için mangal kömürü ile 1sıtılır. Bellerinin etrafında geniş deri kemer giyerler (Şekil 2). Kemer üzerinde dar, hilal şekilli tahtadan yapılmış taşıyıcıda fincan ve zencefil fincanı bulunur. Akortsuz sesleri ile salep, salepi diye bağırmaları duyulur. Onlar salebin çok sağlıklı olduğunu, özellikle gözleri güçlendirdiğine inanırlar" (Işın, 2008).

Salep, şifalı bitkiler içerisinde yer alması nedeniyle eski zamanlarda aktarlarda satılmıştır. Eczanelerin kurulması ile birlikte 50 yıl öncesine kadar salep, eczanelerde satılan bir drog olarak adından bahsettirmiştir. Eczacılar ve Eczaneler Kanunu'na dayanılarak hazırlanan 6197 sayılı 10 Mart 1956 tarihli talimatnamede; eczanelerde satış1 yapılan her türlü maddeler için ambalaj bedelleri belirlenmiş, bu bedel salebin bir gramı için 6 kuruş olarak tanımlanmış; 30 Mayıs 1963'te bu bedel 3 kuruş olarak değiştirilmiştir. $\mathrm{Bu}$ kayıtlardan salebin y1llarca tıbbi bitki olarak eczanelerde satıldığı anlaşılmaktadır (Yaman, 2013).

Sağlık açısından kıymetinin bilinmesi ve besleyici özelliğine istinaden bazı dönemlerde devlet yetkilileri tarafından salep tüketimi teşvik edilmiş, yaygınlaştırılmıştır. Örneğin; 1931 yılına ait Lise ve Orta Mektepler Talimatnamesinin 167. maddesinde, yatılı lise ve ortaokul öğrencilerine kişi başı günlük iki gram salep verilmesi emredilmektedir. Salebin kamu kurumlarına gida olarak tahsis edilmesine ilişkin bilinen en son karar ise; 20 Aralık 1989 tarihli Resmi Gazete'de yayınlanan "Gemi Adamlarının İkamet Yerleri, Sağlık ve İaşelerine Dair Yönetmelik"te yer almıştır. Buna göre gemi adamlarına öğün başı iki gram salep verilmesi istenmiş, böylece iş verimlerinin yükseleceği düşünülmüştür. Salep fiyatları ise resmi gazete arşivlerinde yer almıştır.
Kayıtlara göre Türkiye Cumhuriyeti Hükümeti’nin değişik okullar için ihale usulü ile almak istediği salebin muhammen kilogram fiyati; 7 Haziran 1939'da 250 kuruş, 4 Temmuz 1940'da 450 kuruş, 24 Ağustos 1944'te 10 TL, 11 Ocak 1947'de 15.70 TL, 19 Nisan 1961 'de 68 TL ve 15 Nisan 1972'de 80 TL olarak belirlenmiştir (Yaman, 2013).

\section{Toplama ve Ticari Kayıtlar}

Coğrafi özelliklerin sağlamış olduğu ekolojik farklılıklar sayesinde Anadolu toprakları çok sayıda salep türüne sahiptir. Bu zenginliğe bağlı olarak Türkiye yüzyıllardır en önemli ve en kaliteli saleplerin üretildiği topraklar olmuştur. Anadolu'dan başta Almanya olmak üzere uzun yıllar Avrupa'ya ihracat gerçekleşmiştir. Özel lezzeti sayesinde salebe olan talep hiçbir zaman azalmamıştır. Geçmişte olduğu gibi günümüzde de ihtiyacı karşılamak için gerekli salep yumrularının doğal floradan toplanmasına devam edilmektedir. Çünkü tohum ve yumrular ile çoğaltılmasının önünde engeller vardır. Doğadan toplanılan miktarlar ise azımsanmayacak kadar büyük rakamlara ulaşmaktadır. Burada, bazı kayıtlara değinerek Türkiye tabi florasının salep zenginliği yönünden önemini ortaya koymak gerekir.

Doğadan toplanılan miktarlar ile ilgili ilk kayıtların Evliya Çelebi (1611-1682) tarafından ortaya konulduğu görülmektedir. Evliya Çelebi seyahatnamesinde, Amasya sancağında yıllık 10.000 okka (12.82 ton) salep toplandığından bahsetmiştir. O dönemde 8 kaza (Merkez, Merzifon, Vezirköprü, Osmancık, Gümüşhacıköy, Ladik, Havza, Mecidözü) ile 1201 köy bulunan sancakta 1000 okka bal, 2500 okka afyon üretimine kıyasla toplanılan salep miktarı 12 tonun üzerindedir (Tuzcu, 2007). 


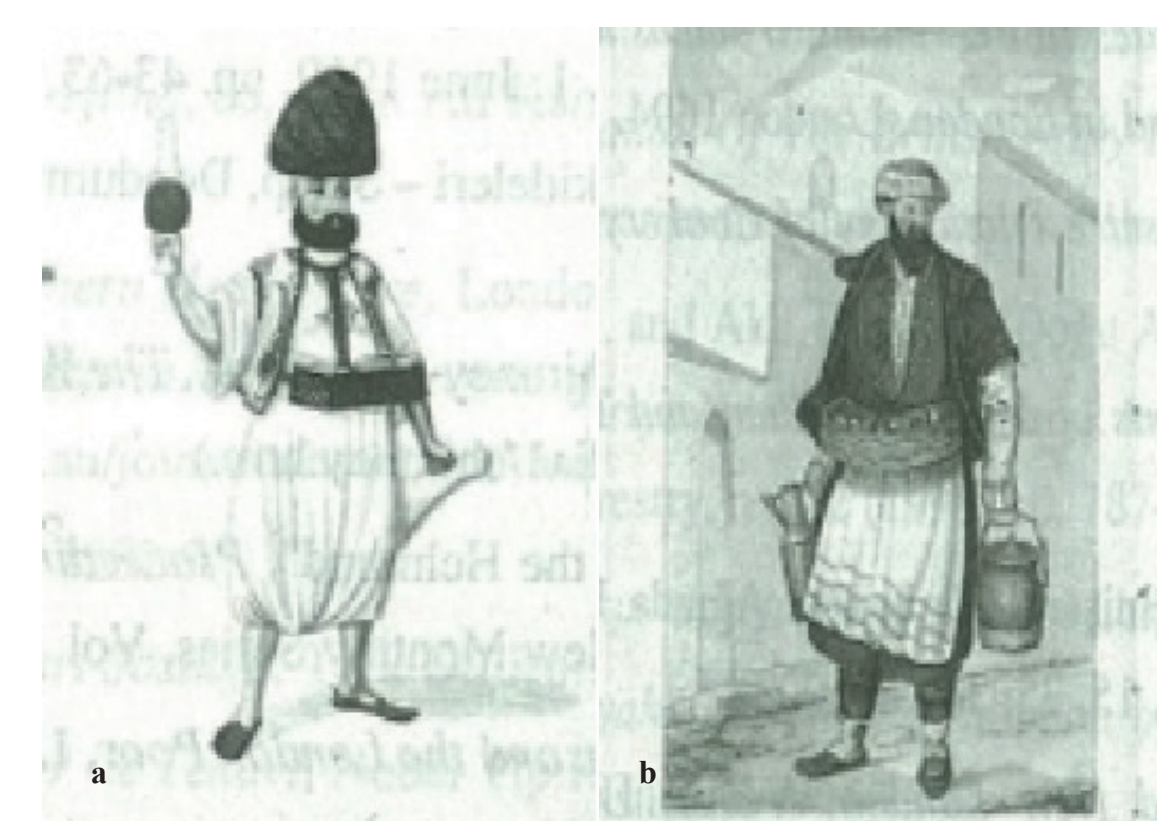

Şekil 2. 17. ve 18. yüzyıllarda salep satıcıları, a; 18. yüzyılda bir salep satıcısı (Ankara Etnoğrafya müzesinde bir albümden), b; 1835'de bir salep satıcısı (Friedrich Unger Atina) (Işıı, 2008)

Salep bahsi, "Ermeni ve Rum Kültür Varlıklarıyla Kayseri” konulu bir çalışmada da geçmektedir. Araştırmada 1875-1880 yılları arasinda Kayseri'nin ithalat ve ihracat hacmini gösteren veriler, Kayseri'nin ileri gelen Ermeni tüccarlardan biri tarafından derlenmiş ve İngiltere'nin Anadolu Konsolos vekili Ferdinand Bennet'e sunulmuştur. Raporda Kayseri bölgesinden yıllık ortalama 3.000 okka (3.85 ton) salep ihracatı yapıldığ 1 ve 400 lira değerinde olduğu belirtilmektedir (Y1lmaz, 2016). Miktar ve fiyat olarak değerlendirildiğinde bir kilogram salebin yaklaşık 10.5 kuruş olduğu anlaşılmaktadır.

Şüphesiz, salebin Türkiye'de en yoğun olduğu alanlardan biri Batı Karadeniz Bölgesi'dir. Bölgeye ait kayıtlarda en net ve yüksek rakamlara Vital Cuinet tarafından yayınlanan araştırmalarda ulaşılmaktadır. Düyun-u Umumiye adına Osmanlı kentlerinin ekonomik, sosyal ve kültürel envanter çalışmalarını yapmakla görevlendirilen Cuinet, Osmanlı'nın ekonomik yapısı hakkında bir envanter çalışması yapmıştır. Vital Cuinet'in yaptı̆̆ı bu çalışmalar daha sonraları 1892'de Paris'te, "La Turquie d'Asie Géographie Administrative" (Asya'nın Türkiye'si-İdari Coğrafiyası) ismi altında kitap olarak yayımlanmıştır (Duran, 2015). "La Turquie d'Asie" adlı eserden Duran (2015)'ın aktardığ 1 verilere göre, Kastamonu sancağında $150.000 \mathrm{~kg}$, Bolu sancağında $45.000 \mathrm{~kg}$ salep toplandığ 1 belirtilmiştir. Aynı eserde, Kastamonu için verilen ihracat rakamlarında ise y1llık 2.000 liralık salep satıldı̆̆ 1 belirtilmektedir. $\mathrm{Bu}$ kadar yüksek miktarda salep toplanması ve satılması Kastamonu ve Bolu civarının salep yönünden çok verimli olduğunu ortaya koymaktadır. Toplanılan miktarlar kelimenin tam anlamiyla devasa boyuttadır. Benzer olarak Mahiroğulları (2003), Osmanlı'nın son döneminde Sivas merkez sancağı için yaptığı sosyo-ekonomik çalışmada Cuinet' in kayıtlarından faydalanmıştır. $\mathrm{Bu}$ kayıtlara göre 1890 yılında Sivas sancağında 15.000 okka salep toplandığ 1 bildirilmiştir.

Osmanlı Devleti 19. yüzyıl ortalarında ziraat bürokrasisini oluşturmaya başlamış ve tarımsal üretimi arttırmayı amaçlamıştır. Bu bağlamda 1846'da Ziraat Nezareti, 1863'te Ziraat Firkası kurulmuştur. Ziraat bürokrasisinin oluşturulmasıyla birlikte, Anadolu ve Rumeli'nin verimli topraklarında iklime uygun yeni ürünlerin yetiştirilmesi için adeta seferberlik başlatılmıştır. Ziraat Meclisi, halkın geçim durumu, ziraatla uğraşacaklara sağlanabilecek imkânlar, boş ve terk edilmiş araziler ve mahalli ulaşım imkânlarını araştırarak projeler geliştirmeye çalışmış ve tarımsal kalkınma devlet politikası haline gelmiştir. Bugün Samsun sahil bandını kapsayan ve Canik sancağı olarak adlandırılan bölgede pamuk, şeker kamış1, ipek kalitesinin arttırılması gibi projeler hazırlanmıştır. Serbestoğlu (2013)'nun bildirdiğine göre Canik sancağında projelendirilen sonuncu ürün ise saleptir. Kavak ve Bafra kazaları başta olmak üzere sancağın bazı yerlerinde değerli salep yetişiyordu. Sivri bir demirle çıkartılan salep, çocukların dahi günde 1.5 kıyye (okka) kadar toplayabileceği ve kıyyesi 18-20 kuruş edecek bir üründü. Salep, şeker kamış1 
veya pamuk gibi halkın genelinin ticaret yapacağ bir ürün değildi. Projeye göre ahali tarafından salep toplanıp, satılacak ve böylece halk küçük de olsa gelir elde etmiş olacaktı.

Sadece iç tüketim değil ihraç ettiğimiz tarım ürünleri içerisinde salep, yüzlerce yıldır önemli bir değer olmuştur. Dünyada en geniş salep çeşitliliğine sahip olan Anadolu toprakları yurt içindeki kullanımın yanı sıra Avrupa'nın ihtiyaçlarını da karşılamıştır. Özellikle popülerlik kazandığı 17.-19. yüzyıllarda Türkiye'den büyük miktarlarda salep ihraç edilmiştir. Örneğin 1825-1826 yillarında 35.000 Frank değerinde salep ihraç edilmiş; 1834 yılında İzmir'den ve diğer bazı komşu limanlardan ihraç edilen ürünler arasında 5000 okka salep yer almış; okkası 11 kuruştan 55.000 kuruş ihraç değeri olduğu bildirilmiştir (Somuncu, 2004). Türkiye'den salep ihracat1 1993 yılına kadar yapılmış olup, bazen 15 tona ulaştığ 1 bildirilmiştir (Erzurumlu ve Doran, 2011). Kasparek ve Grim (1999)'in bildirdiğine göre gümrük kontrol kayıtları 1955 yılından itibaren tutulmaktadır. Araștırıcıların salep ile ilgili hazırladıkları yıllık ihracat rakamları Tablo 1'de görülmektedir. İhracat rakamlarının 1990 yılından sonra artması, toz karışımların ve paketlenmiş hızlı (instant) içeceklerin piyasaya sürülmesinden kaynaklanmaktadır.

Tablo 1. Türkiye'nin 1955-1993 yılları arasında yaptığı salep ihracatı

\begin{tabular}{cccc}
\hline Yil & Salep ihracat1 $(\mathrm{kg})$ & Y1l & Salep ihracat1 $(\mathrm{kg})$ \\
\hline 1955 & 15.386 & 1971 & 1.500 \\
1956 & 5.784 & 1972 & 1.500 \\
1957 & 1.000 & 1973 & 2.224 \\
1958 & 2.400 & 1980 & 449 \\
1959 & 4.540 & 1981 & 861 \\
1960 & 839 & 1984 & 3.245 \\
1961 & 8.571 & 1985 & 4.558 \\
1962 & 5.145 & 1986 & 200 \\
1963 & 12.740 & 1987 & 5.005 \\
1964 & 2.923 & 1988 & 8.221 \\
1965 & 3.889 & 1989 & 5.690 \\
1966 & 320 & 1990 & 29.281 \\
1967 & 1.550 & 1991 & 16.266 \\
1968 & 411 & 1992 & 14.520 \\
1969 & 882 & 1993 & 75.119 \\
1970 & 1.200 & & \\
\hline
\end{tabular}

\section{Yasal Düzenlemeler}

Salep dünya genelinde, son 20-25 yıla kadar, serbestçe toplanılıp satılan doğal kaynaklar içinde yer almıştır. Orta Doğu, Uzak Doğu ve Avrupa ülkelerinde de salep çeşitleri bulunmakta ve yerel halk tarafindan toplanmaktadır.

Geçmişten günümüze tüm salep ihtiyacı doğadan toplama ile karşılanmıştır. Çünkü salep orkidesi tohumları toz zerresi kadar küçüktür ve çimlenen tohumu besleyecek olan besi dokuları yoktur. Bu nedenle yetiştirilemeyen bitkilerdendir. Tabiatta çimlenme şansı bulan tohumların, hasat edilebilir büyüklükte yumru veren bitkilere dönüşmesi için uzun yıllar gereklidir. Ana yumrunun çoğunlukla bir adet yeni yumru üretmesi ve üretilen yeni yumruda bir adet büyüme noktası bulunmas1 ise yumrudan salep çoğaltılmasını engellemektedir (Ar, 2000; Sandal, 2009; Çalışkan, 2018). Dünya genelinde artan salep talebine karşın salep üretiminin yapılamaması önemli bir sorun olarak ortaya çıkmıştır. Yoğun toplama baskısı, salep populasyonlarında azalmaya ve genetik erezyona yol açmaya başlamıştır. Birçok ülke, topraklarında biyoçeşitliliği muhafaza etmek ve gelecek nesillere aktarmak adına önlemler almaya yönelmiştir. Hazırlanan ulusal kanunlar ve uluslararası ortak anlaşmalar ile birçok canlı türünde olduğu gibi salep orkideleri içinde tedbirler alınmakta ve yasalar yürürlüğe konmaktadır.

Uluslararası nitelikte genetik kaynakların korunması adına en geniş kapsamlı sözleşme Birleşmiş Milletler Biyolojik Çeşitlilik sözleşmesidir. Türkiye, yabani florayı, yabani faunayı ve bunların yaşam ortamlarını muhafaza etmek amacıyla Avrupa'nın Yaban Hayatı ve Yaşama Ortamlarını Koruma Sözleşmesi (BERN)'ni 20 Şubat 1984'te imzalamıştır. Ayrıca Türkiye, nesilleri tehlike altında bulunan ya da bulunabilecek türlerin uluslararası ticaretinin izlenmesi, ekolojik dengenin uluslararası ticaret yoluyla istismar edilmesinin önlenmesi ve ülkelerin sahip oldukları biyolojik kaynakların sürdürülebilir kullanımlarının sağlanması için 01 Temmuz 1975'te yürürlüğe giren "Nesli Tehlike Altında Olan Yabani Hayvan ve Bitki Türlerinin Uluslararası Ticaretine İlişkin Sözleşme (CITES)'ye 22 Aralı 1996 tarihinde taraf olmuştur. Orchidaceae familyasının bazı türleri BERN sözleşmesinin ekinde (Ek-1) kesin olarak koruma altına alınan flora türleri içinde yer almaktadır. Orchidaceae familyasının türleri aynı zamanda CITES sözleşmesinin ekinde (Ek-2), henüz tam olarak neslinin tükenmesi tehlikesinin olmamasına rağmen, hayatta kalabilmelerine zıtlık teşkil eden kullanımdan kaçınmak için bu türlerin ticaretinin kesin kurallara bağlanmadığı takdirde nesli tükenebilecek olan türler kategorisinde yer almaktadır (Kasparek ve Grim, 1999; Whigham ve Willems, 2003; Kayıkçı ve Oğur, 2012; Pant, 2013; Ghorbani ve ark., 2014).

Toplam 183 ülkenin imzaladığı CITES sözleşmesinin Ek 2 listesinde yer alan ve dolayısıyla dünya genelinde korumaya alınan salep orkidelerinin toplanmasina kesinlikle izin verilmemektedir. $\mathrm{Bu}$ uluslararası sözleşmelere 
bağlantılı olarak Türkiye'de 09.08.1983 tarihinde kabul edilerek Resmi Gazete'de yayınlanan 2872 no'lu Çevre Kanunu yürürlükte olup, bu kanunun 9/f maddesinde yer alan ifade şöyledir; "Biyolojik çeşitliliğin sürdürülebilirliğinin sağlanması bakımından nesli tehdit veya tehlike altında olanlar ile nadir bitki ve hayvan türlerinin korunması esas olup, mevzuata aykırı biçimde ticarete konu edilmeleri yasaktır." (Anonim, 2019a).

Kanunun bu maddesi CITES sözleşmesine göre tüm salep orkidesi türlerini içine almaktadır. Bu yasağa uymayanlar hakkında Çevre Kanunu'nun 20. maddesinde uygulanacak para cezaları belirtilmiş; 2019 yılı için yapılan düzenlemede 01/01/2019-31/12/2019 tarihleri arasinda kanundaki ceza miktarı 60.000 Türk Lirası olarak yer almıştır (Anonim, 2019b).

\section{Sonuçlar}

Tüm yasaklamalara karşın Türkiye'de yıllık yaklaşık 500 ton civarında taze salep yumrusu toplanmakta ve bundan ortalama 80-100 ton salep unu üretilmektedir. Bu değerler alıcılardan edinilen resmi olmayan rakamlardır. Zira toplayıcılığının yasak olması nedeniyle kaçak olarak satılmakta, resmi kayıt bulunmamaktadır. Benzer olarak çevre ülkelerde de salep orkidelerinin toplandığ1 bilinmektedir. $\mathrm{Bu}$ olumsuzluk her y1l milyonlarca salep orkidesinin doğal ortamlarından koparılmasına ve türlerin populasyonlarının zarar görmesine, genetik erozyonun artmasına yol açmaktadır. Yapılması gereken acil müdahale; salep tarımının geliştirilerek, tarla ziraati şeklinde üretiminin sağlanmasıdır.

\section{Kaynaklar}

Anonim, 2019a. Çevre Kanunu. (www.mevzuat.gov/ MevzuatMetin/1.5.2872.doc.), (Erişim tarihi: 06.03.2019).

Anonim, 2019b. Cezalar. (http://www.resmigazete. gov.tr/eskiler/2018/12/20181231-6-1.pdf.), (Erişim tarihi: 06.03.2019).

Ar, E., 2000. Orkideler ve Türkiye'deki mevcut durum. Derim, 17(3): 136-152.

Attri, L.K., 2016. Therapeutic potential of orchids. World Journal of Pharmacy and Pharmacetical Science, 5(2): 438-446.

Bonte, F., Cakova, V., Lobstein, A., 2013. Medicinal uses of orchids in Europe ( $16^{\text {th }}-18^{\text {th }}$ century). $41^{\text {st }}$ International Congress for the History of Pharmacy in Paris, 10-14 September, Paris, Fransa, pp. 96.

Bulpitt, C.J., 2005. The uses and misuses of orchids in medicine. QJM: An International Journal of Medicine, 98(9): 625-631.

Çalışkan, Ö., 2018. Salep Orkideleri. Erol Ofset, Samsun.
Duran, S., 2015. 1869-1916 Kastamonu ve Bolu Salnamelerinde Ereğli. Post Yayınları, Ankara.

Erzurumlu, G.S., Doran, İ., 2011. Türkiye'de salep orkideleri ve salep kültürü. Harran Üniversitesi Ziraat Fakültesi Dergisi, 15(1): 29-34.

Ghorbani, A., Gravendeel, B., Zarre, S., Boer, H., 2014. İllegal wild collection and international trade of Cites listed terretrial orchid tubers in İran. Traffic Bulletin, 26(2): 53-58.

Gümüş, C., 2009. Batı Karadeniz bölgesinde salep elde edilmesinde kullanılan bazı orkide türlerinin çoğaltım yöntemleri üzerine araştırmalar. Doktora tezi, Ankara Üniversitesi Fen Bilimleri Enstitüsü, Ankara.

Hossain, M.M., 2011. Therapeutic orchids: traditional uses and recent advances-An overview. Fitoterapia, 82(2): 102-140.

Işın, M.P., 2008. Salep, spiced winter drink and cure-all (Salep, Rahat-1 Can Sihhatü'l-Ebdan Talim-i Nefayis). 1. Uluslararası Tip Tarihi Kongresi ve 10. Ulusal Tip Tarihi Kongresi, 20-24 May1s, Konya, Türkiye, pp. 613-625.

Jalal, J.S., Kumar, P., Pangtey, Y.P.S., 2008. Ethnomedicinal orchids of Uttarakhand, Western Himalaya. Etnobotanical Leaflets, 12: 1227-1230.

Kasparek, M., Grim, U., 1999. European trade in Turkish salep with special reference to Germany. Economic Botany, 53(4): 396-406.

Kayıķı, S., Oğur, E., 2012. Hatay ilinde yayılış gösteren bazı orkide türleri üzerine bir inceleme. Anadolu Ege Tarımsal Araştırma Enstitüsü Dergisi, 22(2): 1-12.

Kreutz, C.A.J., 2002. Türkiye'nin orkideleri, salep, dondurma ve katliam. Yeşil Atlas, 5: 98-109.

Kreziou, A., De Boer, H., Gravendeel, B., 2016. Harvesting of salep orchids in north-western Greece continues to threaten natural populations. Oryx, Fauna \& Flora International, 50(3): 393-396.

Mahiroğulları, A., 2003. XIX. yüzyılın ortalarından birinci dünya savaşına kadar Sivas'ın sosyo ekonomik yapısı. İstanbul Üniversitesi Sosyoloji Konferanslarl Dergisi, 27: 49-73.

Pala, İ., 2010. Osmanlı döneminde saray mutfağında kullanılan pişmiş toprak sunum kaplarının form özellikleri. Sanatta yeterlilik tezi, Dokuz Eylül Üniversitesi Güzel Sanatlar Enstitüsü, İzmir.

Pant, B., 2013. Medicinal orchids and their uses: Tissue culture a potential alternative for conservation. African Journal of Plant Science, 7(10): 448-467.

Sandal, G., 2009. Doğu Akdeniz bölgesinde yetişen orkideler ve yetișme ortamı nitelikleri ile tehdit faktörlerinin araştırılması. Doktora tezi, Çukurova Üniversitesi Fen Bilimleri Enstitüsü, Adana.

Serbestoğlu, İ., 2013. Canik Sancağında tarımsal kalkınma teşebbüsü (1860-1870). Tarih boyunca Karadeniz ticareti ve Canik. Canik Belediyesi Kültür Yayınları, No: 55-13-01, Samsun.

Singh, D.R., Kishore, R., Kumar, R., Singh, A., 2016. Orchid preparations. Technical Bulletin, National Research Centre for Orchids, (https://www. 
nrcorchids.nic.in/images/Orchid-Preparations_Tech nical-Bulletin1.pdf), (Erişim tarihi: 01.10.2019).

Singh, S., Singh, A.K., Kumar, S., Kumar, M., Pandey, P.K., Singh, M.C.K., 2012. Medicinal properties and uses of orchids: a concise review. Elixir Applied Botany, 52: 11627-11634.

Somuncu, M., 2004. Cehri üretimi ve ticaretinin 19. yüzyılda Kayseri ekonomisindeki önemi. Erciyes Üniversitesi İktisadi ve İdari Bilimler Fakültesi Dergisi, 22: 99-125.

Şen, M.A., 2017. Osmanlı mutfağından günümüze gastronomik değerimiz "Salep". Eurasian Academia of Social Science Journal, Özel Say1: 260-270.

Tığlı, E.H., 2015. Bucak (Burdur) yöresinde bazı doğal orkide türlerinin yayılış alanları, morfolojik ve fenolojik özellikleri. Yüksek lisans tezi, Süleyman Demirel Üniversitesi Fen Bilimleri Enstitüsü, Isparta.
Turgay, Ö., Çınar, İ., 2017. Salep: the name of plant, powder, hot beverage, food ingredient. Kahramanmaraşs Sütçü İmam Üniversitesi Mühendislik Bilimleri Dergisi, 20(3): 68-71.

Tuzcu, A., 2007. Seyahatnamelerde Amasya. Amasya Belediyesi Kültür Yayınları, Amasya.

Whigham, D.F., Willems, J.H., 2003. Demographic studies and life-history strategies of temperate terrestrial orchids as a basis for conservation. In: W. Kingsley Dixon, P. Shelagh, R. L. Barrett and Philip Cribb (Eds.), Orchid conservation, 1st edition, Kota Kinabaluk Sabah, Malaysia, pp. 137-158.

Yaman, K., 2013. 1920'den günümüze T.C. Resmi Gazete arşivinde salep ve ticareti ile ilgili yasal düzenlemeler. Tarih Kültür ve Sanat Araştırmaları Dergisi, 2(1): 172-180.

Yılmaz, A., 2016. Ermeni ve Rum Kültür Varlıklarıyla Kayseri. HDV Yayınları, İstanbul. 